\title{
PENDIDIKAN KARAKTER PERILAKU SOSIAL ANAK USIA SEKOLAH DASAR DALAM KELUARGA DI KOTA BANJARMASIN
}

\author{
Taufiqurrahman ${ }^{1 *}$ dan Najminnur Hasanatun $\mathrm{Nida}^{2}$ \\ Program Studi Pendidikan Agama Islam \\ Fakultas Tarbiyah dan Keguruan Universitas Islam Negeri Antasari \\ *Email: taufiqurrahman@uin-antasari.ac.id \\ Website : https://jurnal.uin-antasari.ac.id/index.php/jtjik/index \\ Received: Mei 2019; Accepted: Agustus 2019; Published: Agutus 2019
}

\begin{abstract}
This study aimed to analyze the strategies of parents and teachers through collaboration in strengthening character education. This study used community study research with population of 500 parents in 5 sub-districts of Banjarmasin City. The sample was 200 parents of students using the snow-ball method. Data were collected by interviews, observation, participation, and documentation. Then, data were verified through credibility, transferability, criteria, confirmation, and triangulation of data with respondents. The results showed that the basis and philosophy of social behavior character education namely introduction and practice can build character of students' social behavior towards religion, Pancasila and Banjar culture. Children are guided and get guidelines with exemplary, discipline, motivation, habituation, conducive preservation and development as well as an educational atmosphere that helps develop their social environment. Furthermore, parents have a pattern to guide the character of children's social behavior by applying democratic leadership attitudes based on the character development of children's social behavior. In addition, character education is also influenced by the collaboration and strengthening of harmony between parents and teachers which is carried out intensively and continuously.
\end{abstract}

Keywords : family education pattern; character building; child character; social behaviour

\begin{abstract}
ABSTRAK
Penelitian ini bertujuan untuk menganalisis strategi orang tua dan guru melalui kerjasama dalam penguatan pendidikan karakter. Penelitian ini menggunakan penelitian studi komunitas. Populasi adalah lima ratus orangtua siswa di lima kecamatan Kota Banjarmasin. Sampel adalah dua ratus orangtua siswa yang dipilih menggunakan metode snowball sampling. Data dikumpulkan dengan wawancara, observasi, partisipasi, dan dokumentasi. Data di verifikasi, melalui kredibilitas, transferabilitas, kriteria, konfirmasi, serta triangulasi data dengan responden. Hasil penelitian menunjukan bahwa dengan dasar dan falsafah pendidikan karakter perilaku sosial yakni pengenalan dan pengamalan, dapat membangun karakter perilaku sosial siswa terhadap agama, Pancasila dan budaya Banjar. Anak-anak dibimbing dan mendapat pedoman dengan keteladanan, disiplin, motivasi, pembiasaan, pelestarian dan pengembangan yang kondusif serta suasana pendidikan yang membantu mengembangkan lingkungan sosialnya. Orangtua memiliki pola untuk membimbing karakter perilaku sosial anak dengan menerapkan sikap kepemimpinan secara demokratis berdasarkan perkembangan karakter perilaku sosial anak. Selain itu, pendidikan karakter juga dipengaruhi oleh kerjasama dan penguatan yang harmonis antara orangtua dan guru yang dilakukan secara intensif dan kontinu. Kata Kunci : pendidikan keluarga; pembinaan karakter; karakter anak; perilaku sosial
\end{abstract}




\section{PENDAHULUAN}

Pendidikan karakter perilaku sosial akhir-akhir ini semakin banyak diperbincangkan, terutama di kalangan akademisi. Hal ini disebabkan sikap dan perilaku masyarakat Indonesia yang cenderung mengabaikan nilai-nilai luhur yang sudah lama dijunjung tinggi dan mengakar dalam sikap dan perilaku seharihari. Kejujuran, kesantunan, kebersamaan, dan nilai keagamaan perlahan mulai tergerus oleh budaya asing yang cenderung hedonistik, materialistik dan individualistik sehingga nilai-nilai karakter perilaku sosial tersebut tidak lagi dianggap penting.

Kebijakan UU No 20 Tahun 2003 Tentang Sistem Pendidikan Nasional pada Pasal 3 menyebutkan bahwa pendidikan nasional berfungsi mengembangkan kemampuan dan membentuk karakter serta peradaban bangsa yang bermartabat dalam rangka mencerdaskan kehidupan bangsa. Pendidikan nasional bertujuan untuk mengembangkan potensi peserta didik agar menjadi manusia yang beriman dan bertakwa kepada Tuhan Yang Maha Esa, berakhlak mulia, sehat, berilmu, cakap, kreatif, mandiri dan menjadi warga negara yang demokratis serta bertanggung jawab.

Kebijakan tersebut sebagai tindak lanjut dari kebijakan PP Nomor 17 Tahun 2010 tentang Pengelolaan Penyelenggaraan Pendidikan pada Pasal 17 ayat (3) yang menyebutkan bahwa pendidikan dasar bertujuan membangun landasan bagi berkembangnya potensi peserta didik agar menjadi manusia yang (a) beriman dan bertakwa kepada Tuhan Yang Maha Esa; (b) berakhlak mulia dan berkepribadian luhur; (c) berilmu, cakap, kritis, kreatif dan inovatif; (c) sehat, mandiri dan percaya diri; (d) toleran, peka sosial, demokratis dan bertanggung jawab.

Berdasarkan kedua kebijakan tersebut, jelas bahwa tujuan pendidikan di setiap jenjang, termasuk sekolah dasar sangat berkaitan dengan pembentukan karakter peserta didik, baik bentukan dari sekolah maupun sinergik dengan pembentukan karakter di lingkungan rumah oleh orangtua secara konsisten dan kontinu, dalam rangka membina kepribadian bangsa yang bermartabat dan berkualitas menyambut era millennium 4 (empat).

Menurut Muhajir Effendy yang dikutip dari Republika Online (2016), kebijakan pendidikan kita selama ini melewatkan dan mengabaikan beberapa dimensi penting dalam pendidikan, yaitu olah raga (kinestetik), olah rasa (seni) dan olah hati (hati dan spiritual) sehingga apa yang selama ini kita lakukan baru sebatas olah pikir yang menumbuhkan kecerdasan akademis.

Pengertian karakter identik dengan kepribadian dan akhlak sehingga karakter merupakan nilai-nilai perilaku manusia yang universal yang meliputi seluruh aktivitas manusia, baik dalam rangka berhubungan dengan Tuhannya, dengan dirinya, dengan sesama manusia, maupun dengan alam lingkungannya yang terwujud dalam pikiran, sikap, perasaan, perkataan dan perbuatan berdasarkan norma-norma agama, hukum, tata karma, budaya Pancasila dan adat istiadat yang melembaga di masyarakat. Dari kebijakan konsep karakter ini muncul konsep pendidikan karakter (character education). Amin (1995 : 62) menyatakan bahwa pendidikan karakter ini sebagai awal terjadinya akhlak (karakter) pada diri seseorang, jika kehendak itu diwujudkan dalam bentuk pembiasaan sikap dan perilaku.

Karakter perilaku sosial adalah suasana saling ketergantungan yang merupakan keharusan untuk menjamin keberadaan manusia. Karakter perilaku sosial seseorang itu tampak dalam pola respons antar orang yang dinyatakan dengan hubungan timbal balik antar pribadi (Ibrahim, 2012 : 53). Menurut pakar psikologi pendidikan, yang menjadi dasar sesungguhnya dari karakter perilaku sosial pada hakikatnya adalah manusia sebagai makhluk sosial (Lickona 2003 : 28).

Pembentukan karakter perilaku sosial seseorang dipengaruhi oleh berbagai faktor baik yang bersifat internal maupun yang bersifat eksternal. Pada aspek eksternal 
situasi sosial memegang peranan yang cukup penting. Situasi sosial diartikan sebagai situasi yang menunjukkan adanya hubungan antara manusia yang satu dengan yang lain (Gerungan, 1987 : 77). Contoh situasi sosial misalnya lingkungan pasar, saat rapat, atau dalam lingkungan pembelajaran.

Masyarakat berpendidikan wajib menjunjung tinggi karakter mulia (akhlak karimah) yang lebih dipertegas oleh Nabi saw. dengan pernyataan yang menghubungkan akhlak dengan kualitas iman, bobot amal dan jaminan masuk surga. Sabda Nabi saw. yang diriwayatkan oleh Abdullah Ibn Amr: "Sebaik-baik kamu adalah yang paling baik akhlaknya ..." (HR.al-Tirmidzi). Dalam hadis yang lain Nabi saw. bersabda: "Sesungguhnya orang yang paling cinta kepadaku di antara kamu sekalian dan paling dekat tempat duduknya denganku di hari kiamat adalah yang terbaik akhlaknya di antara kamu sekalian ..." (HR.al-Tirmidz).

Dalam pandangan Islam sendiri sejatinya pendidikan karakter dan pembinaan akhlak dalam keluarga ini secara dogmatis sudah lengkap tertulis dalam Alquran dan Sunnah Nabi saw. Bahkan Islam mendudukkan pendidikan karakter perilaku sosial atau akhlak sebagai barometer kebaikan seseorang dan sebagai salah satu syarat sempurnanya keimanan seseorang. Rasulullah saw. bersabda: " $A k u$ tidak akan diutus kedunia ini, kecuali untuk menyempurnakan akhlak manusia".

Kebijakan UU Pendidikan tentang Sistem Pendidikan Nasional Nomor 2 tahun 2013 tentang kebijakan pendidikan dasar 9 tahun lebih mengutamakan pengetahuan bidang umum dan khususnya peningkatan keterampilan, mempersiapkan peserta didik untuk bekerja dan meningkatkan kemampuan dalam melaksanakan tugas tertentu.

Kebijakan ini ditindak lanjuti oleh Pasal 10 ayat 4 UU SPN menyatakan bahwa pendidikan keluarga merupakan bagian dari jalur pendidikan luar sekolah yang diselenggarakan dalam keluarga yang lebih berorientasi pada pemberian keyakinan karakter beragama, karakter budaya, karakter moral, karakter prilaku sosial dan keterampilan.

Pendidikan anak yang pertama dan paling utama dalam Islam adalah pendidikan dalam keluarga yang berperspektif Islam. Pendidikan dalam keluarga yang berperspektif Islam adalah pendidikan yang didasarkan pada tuntunan agama Islam yang diterapkan dalam keluarga yang dimaksudkan untuk membentuk anak agar menjadi manusia yang beriman dan bertaqwa pada Tuhan Yang Maha Esa, serta berakhlak mulia yang mencakup etika, moral, budi pekerti, spiritual atau pemahaman dan pengalaman nilai-nilai keagamaan dalam kehidupan sehari-hari yang nantinya hal itu merupakan sumbangan penting bagi pembangunan bangsa dan negara.

Tanggung jawab besar orang tua untuk mendidik anak menjadi pribadi yang shaleh tertuang dalam firman Allah Swt surat al-Tahrim ayat 6 , yang artinya:

"Hai orang-orang yang beriman, peliharalah dirimu dan keluargamu dari api neraka yang bahan bakarnya adalah manusia dan batu; penjaganya malaikatmalaikat yang kasar, keras dan tidak mendurhakai Allah terhadap apa yang diperintahkan-Nya kepada mereka dan selalu mengerjakan apa yang diperintahkan."

Dari hasil studi eksplorasi yang peneliti lakukan terdapat adanya kesenjangan faktor positif dan faktor yang negatif dari perkembangan pendidikan perilaku sosial. Masalah yang ditemukan antara lain: berkurangnya sikap hormat anak pada orangtua dan berkurangnya sikap hormat murid pada gurunya, berkurangnya sikap suka menolong anak pada keluarga, teman dan lingkungan tempat tinggal, berkurangnya kebiasaan suka berempati dan bersedekah, berkurangnya sikap menghargai sesama teman, sering terjadi perselisihan antara teman, sering terjadi tawuran antar sekolah, anak sering berontak pada orangtua, anak usia sekolah dasar sudah mulai terlibat napza, anak terlalu sibuk dengan gadget 
sampai tidak perduli dengan lingkungan dimana mereka sedang berada.

Faktor positif yang bertahan dalam memperbaiki perilaku sosial yaitu: banyaknya keluarga muslim yang mengajarkan aqidah akhlak, banyaknya tempat ibadah dan pengajian agama Islam, banyaknya lembaga pendidikan non formal dan lembaga pendidikan formal yang berkualitas, budaya adat Banjar yang ramah suka gotong royong dan bersedekah. Dari pihak sekolah, adanya penguatan pendidikan karakter di sekolah yang dilaksanakan secara konsisten dan kontinu.

Untuk melihat implementasi pendidikan karakter perilaku sosial yang ideal, maka penelitian ini akan mengkaji "Pendidikan Karakter Perilaku Sosial Anak Usia Sekolah Dasar di Kota Banjarmasin".

\section{METODE PENELITIAN}

Penelitian ini menggunakan pendekatan empirik kualitatif secara alamiah (natural setting) sebagai sumber data langsung dimana peneliti sendiri sebagai instrumen kunci. Jenis penelitian ini berupa studi eksploratif dalam bentuk studi masyarakat (community studies), yakni penelitian yang mendalam pada satu setting atau suatu latar atau subyek tunggal atau satu peristiwa tertentu.

Penelitian ini menggunakan penelitian studi komunitas dengan populasi 500 (lima ratus) orangtua siswa di 5 (lima) Kecamatan Kota Banjarmasin. Sampel adalah 200 (dua ratus) orangtua siswa dengan yang dipilih menggunakan metode snowball sampling. Data dikumpulkan dengan wawancara, observasi partisipasi dan dokumentasi. Data selanjutnya diverifikasi, melalui kredibilitas, transferabilitas, kriteria, konfirmasi, serta triangulasi data dengan responden.

\section{HASIL DAN PEMBAHASAN}

\section{A. Hasil Penelitian}

Profil kota Banjarmasin :

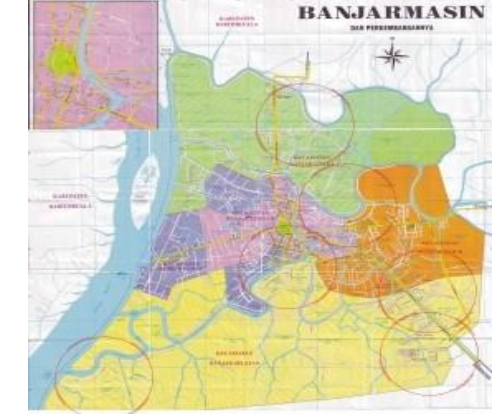

\section{Gambar 1. Peta kota Banjarmasin}

Kota Banjarmasin adalah ibu kota provinsi Kalimantan Selatan, Indonesia. Banjarmasin yang dijuluki Kota Seribu Sungai ini memiliki wilayah seluas $98,46 \mathrm{~km}^{2}$ yang wilayahnya merupakan delta atau kepulauan yang terdiri dari sekitar 25 buah pulau kecil (delta) yang dipisahkan oleh sungai-sungai di antaranya pulau Tatas, pulau Kelayan, pulau Rantauan Keliling, pulau Insan dan lain-lain. Berdasarkan data BPS Kota Banjarmasin tahun 2017, Banjarmasin memiliki penduduk sebanyak 675.440 jiwa dengan kepadatan 9.381 jiwa per $\mathrm{km}^{2}$. Wilayah metropolitan Banjarmasin yaitu Banjar Bakula memiliki penduduk sekitar 1,9 juta jiwa.

\section{Geografis}

Kota Banjarmasin terletak pada $3^{\circ} 15^{\prime}$ sampai $3^{\circ} 22^{\prime}$ Lintang Selatan dan $114^{\circ} 32^{\prime}$ Bujur Timur, ketinggian tanah asli berada pada $0,16 \mathrm{~m}$ di bawah permukaan laut dan hampir seluruh wilayah digenangi air pada saat pasang. Kota Banjarmasin berlokasi daerah kuala sungai Martapura yang bermuara pada sisi timur Sungai Barito. Letak Kota Banjarmasin nyaris di tengahtengah Indonesia.

Kota ini terletak di tepian timur sungai Barito dan dibelah oleh sungai Martapura yang berhulu di pegunungan Meratus. Kota Banjarmasin dipengaruhi oleh pasang surut air laut Jawa sehingga berpengaruh kepada drainase kota dan memberikan ciri khas tersendiri terhadap kehidupan masyarakat, terutama pemanfaatan sungai sebagai salah satu prasarana transportasi air, pariwisata, perikanan dan perdagangan. 
2. Demografi

Kota Banjarmasin terdiri atas 5

b. Banjarmasin Selatan: $38,27 \mathrm{~km}^{2}$

kecamatan, yaitu:

c. Banjarmasin Tengah: $6,66 \mathrm{~km}^{2}$

d. Banjarmasin Timur: $23,86 \mathrm{~km}^{2}$

a. Banjarmasin Barat: $13,13 \mathrm{~km}^{2}$

e. Banjarmasin Utara: $16,54 \mathrm{~km}^{2}$

Jumlah penduduk di wilayah Banjarmasin diperincikan sebagai berikut:

Tabel 1. Jumlah penduduk menurut jenis kelamin (jiwa) tahun 2018:

\begin{tabular}{|c|c|c|c|c|}
\hline No. & Kecamatan & Laki-Laki & Perempuan & Jumlah \\
\hline 1. & Banjarmasin Selatan & 79.528 & 78.150 & 157.678 \\
\hline 2. & Banjarmasin Timur & 59.846 & 60.216 & 120.062 \\
\hline 3. & Banjarmasin Barat & 75.952 & 73.780 & 149.732 \\
\hline 4. & Banjarmasin Tengah & 46.708 & 48.042 & 94.750 \\
\hline 5. & Banjarmasin Utara & 76.099 & 77.119 & 153.218 \\
\hline & Jumlah/Total & 338.133 & 337.307 & 675.440 \\
\hline
\end{tabular}

Sumber : BPS Kota Banjarmasin

Tabel 2. Jumlah penduduk yang bekerja menurut lapangan usaha dan jenis kelamin (jiwa) tahun 2018:

\begin{tabular}{|c|l|c|c|c|}
\hline No. & \multicolumn{1}{|c|}{ Lapangan Pekerjaan } & Laki-Laki & Perempuan & Jumlah \\
\hline 1. & Pertanian & 3.483 & 407 & 3890 \\
\hline 2. & Pertambangan & 2.882 & - & 2882 \\
\hline 3. & Industri Pengolahan & 13.754 & 4302 & 18.056 \\
\hline 4. & Listrik dan Gas & 1.970 & - & 1.970 \\
\hline 5. & Konstruksi & 24.253 & 537 & 24.790 \\
\hline 6. & Perdagangan, Hotel, dan Restoran & 65.327 & 58.232 & 123.559 \\
\hline 7. & Angkutan dan Komunikasi & 30.411 & 2.811 & 33.222 \\
\hline 8. & Keuangan & 8.485 & 683 & 9.168 \\
\hline 9. & Jasa-Jasa dan Lainnya & 37.798 & 37.836 & 75.634 \\
\hline & Jumlah/Total & 188.363 & 104.808 & 293.171 \\
\hline
\end{tabular}

Sumber : SAKERNAS, BPS Kota Banjarmasin 2018

Tabel 3. Jumlah sekolah, kelas, ruang kelas, murid dan guru pada SD Negeri per Kecamatan, 2017/2018:

\begin{tabular}{|c|c|c|c|c|c|c|c|c|}
\hline \multirow{2}{*}{ No } & \multirow{2}{*}{ Kecamatan } & \multirow{2}{*}{ Sekolah } & \multirow{2}{*}{ Kelas } & \multirow{2}{*}{ Ruang } & \multirow{2}{*}{ Murid } & \multicolumn{2}{|c|}{ Guru } & \multirow{2}{*}{ Jumlah } \\
\hline & & & & & & $\mathbf{L k}$ & Pr & \\
\hline 1. & Banjarmasin Selatan & 59 & 425 & 12.813 & 191 & 444 & 635 & 59 \\
\hline 2. & Banjarmasin Timur & 41 & 329 & 10.622 & 122 & 418 & 540 & 41 \\
\hline 3. & Banjarmasin Barat & 41 & 347 & 10.926 & 154 & 384 & 538 & 41 \\
\hline 4. & Banjarmasin Tengah & 26 & 278 & 7.927 & 78 & 196 & 274 & 26 \\
\hline 5. & Banjarmasin Utara & 39 & 284 & 9.995 & 110 & 343 & 453 & 39 \\
\hline & Jumlah / Total & 206 & 1.663 & 52.283 & 655 & 1.785 & 2.440 & 206 \\
\hline & $2016 / 2017$ & 206 & 1.701 & 52.422 & 733 & 1.790 & 2.523 & 206 \\
\hline & $2015 / 2016$ & 206 & 1.699 & 54.586 & 779 & 2.199 & 2.978 & 206 \\
\hline & $2014 / 2015$ & 205 & 1.654 & 54.774 & 682 & 1.971 & 2.653 & 205 \\
\hline
\end{tabular}

Sumber : Dinas Pendidikan Kota Banjarmasin

\section{Peran Orang Tua Dalam Pendidikan Karakter Perilaku Sosial Anak}

1. Identitas Keluarga Siswa

a. Tingkat Pendidikan Orangtua

Dari jumlah populasi responden orangtua siswa sekolah dasar yang diteliti, ditemukan data bahwa orangtua yang berpendidikan tamat SD sebanyak 58 orang, tamat SLTP sebanyak
72 orang, tamat SLTA sebanyak 209 orang, diploma sebanyak 71 orang, S1 sebanyak 73 orang dan S2 sebanyak 37 orang. Jadi, dari 500 orang kepala keluarga, kebanyakan orangtua berpendidikan tingkat sekolah lanjutan ke bawah. Dari populasi tersebut di ambil 200 respoden yang anaknya sekolah pada sekolah dasar yang sudah menerapkan kurikulum 2013 secara utuh dan ada kerjasama serta penguatan 
pendidikan karakter dengan sekolah dan guruguru. Orangtua siswa di sekolah ini rata-rata berpendidikan sekolah menengah ke atas dan mempunyai tingkat ekonomi menengah ke atas. b. Jenis Pekerjaan

Orangtua siswa yang bekerja sebagai petani 57 orang, buruh toko 80 orang, buruh perusahaan 63 orang, pedagang kecil 54 orang, pedagang besar 100 orang, pegawai negeri 90 orang dan pegawai perusahaan 56 orang.

c. Tingkat Ekonomi

Pekerjaan petani, buruh dan pedagang kecil berada pada tingkat ekonomi menengah ke bawah, sedangkan pedagang besar dan pegawai negeri berada pada tingkat ekonomi menengah ke atas. Namun, mereka sama-sama kurang mempunyai waktu kebersamaan dengan anak-anak mereka.

d. Gaya Kepemimpinan Orangtua

Para orangtua di Banjarmasin memiliki filosofis kepemimpinan yang bernuansa relegius, yaitu mereka menganggap bahwa bekerja dan mempersiapkan masa depan anakanak menjadi generasi yang cerdas dan berakhlak mulia adalah suatu ibadah. Mendidik karakter perilaku sosial pada anak juga merupakan suatu ibadah sehingga dalam mendidik karakter anak, orangtua perlu bekerjasama dengan sekolah. Peran orangtua, terlebih ibu, dan anggota keluarga lain memberikan dampak yang lebih besar terhadap karakter beragama anak sehingga setiap saat harus membimbing dan menjaga serta mengontrol anak-anak kearah karakter beragama, yaitu akhlakul karimah.

Suku Banjar sebagian besar menerapkan kepemimpinan demokratis dan sebagian lagi liberal dan campuran. Suku Jawa dan Madura sebagian besar memakai kepemimpinan liberal dan sebagian lagi kepemimpinan otoriter. Kepemimpinan demokratis terjadi ketika orangtua menyodorkan gagasan-gagasan, ideide yang inovatif dan kreatif yang disosialisasikan kepada anak-anak sehingga anak-anak mendapat kesempatan untuk menyumbangkan pemikirannya, seperti memilih sekolah dan belajar aktif yang dapat membantu prestasi belajar anak-anak. e. Pandangan Orangtua terhadap budaya dan teknologi

Orangtua tidak tertutup terhadap pengembangan ilmu pengetahuan dan teknologi selama mengarah kepada hal-hal yang positif. Namun, orangtua juga merasa takut dengan akibat pengaruh negatif dari pemanfaatan teknologi karena orangtua tidak terlalu banyak waktu untuk bersama dengan anak-anak, apalagi mengadakan pendampingan dan pengawasan. Hal ini disebabkan kebanyakan orangtua bekerja di luar rumah seharian. Bagi orangtua yang berpenghasilan lebih, mereka lebih memilih untuk menyekolahkan anaknya ke sekolah unggulan full day school atau mengantar anaknya ke pondok pesantren dan rumah tahfiz.

2. Nilai-Nilai yang Dijadikan Dasar dan Tujuan Orang Tua Dalam Mendidik

Karakter perilaku sosial anak/ falsafah hidup yang menjadi pedoman orangtua:

a. Keagamaan.

Responden rata-rata beragama Islam, maka dasar-dasar ke-Islamanlah yang dijadikan landasan bagi orangtua untuk mendidik anak-anak mereka.

b. Kebudayaan.

Kebanyakan orang tua mendidik anaknya dengan budaya Islam dan budaya masyarakat Banjar yang diterapkan dalam kehidupan sehari-hari.

\section{Lingkungan Budaya Orangtua}

Suatu budaya bagi masyarakat di Banjarmasin untuk melibatkan anak-anak mereka dalam melaksanakan acara keagamaan seperti acara Yasinan, Shalawat Burdah, Shalawat Dalailul Khairat dan Maulid al-Habsyi yang dilanjutkan dengan ceramah agama yang dilaksanakan secara rutin setiap minggu. Demikian juga pada peringatan hari besar Islam seperti Maulidur Rasul, Tahun Baru Islam, Nuzulul Qur'an, serta acara Rajabiyah yang diselenggarakan setiap tahun juga selalu melibatkan anakanak mereka.

Bagi masyarakat yang bekerja sebagai pegawai negeri dan swasta, majelis ta'lim 
biasanya juga dilaksanakan di aula kantor setiap setengah bulan sekali secara rutin. Pada kegiatan inilah orangtua siswa yang bekerja sebagai buruh perusahaan menambah pengetahuan agama Islam.

Pihak sekolah menanamkan pendidikan karakter dengan strategi utama melalui pembiasaan dalam kehidupan sehari-hari baik di sekolah maupun di rumah. Pembiasaan di sekolah dengan menerapkan peraturan sekolah dengan beberapa disiplin, sedangkan pembiasaan di rumah dilakukan oleh orangtua melalui panduan buku penghubung. Buku penghubung harus ditanda tangani oleh orangtua. Di sekolah, guru membiasakan anak-anak untuk memberi infak setiap ada teman yang sakit sekaligus mendoakan kesembuhannya, sebagai wujud empati anak pada sesama. Selain itu, di sekolah juga dilatih disiplin membaca Alquran bersama, sholat Dhuha dan sholat Zuhur berjamaah. Siswa yang terlambat diberikan hukuman yang sifatnya mendidik seperti menyapu pekarangan sekolah atau membersihkan kelas.

Kerjasama orangtua dan guru di sekolah menekankan keutuhan dan keterpaduan antara pengetahuan, sikap dan perilaku sosial atau lebih menekankan pembentukan ranah afektif dan psikomotorik yang dilandasi oleh ranah kognitif. Guru dan orangtua bekerjasama membentuk kepribadian anak beriman dan untuk memperbaiki akhlak anak-anak. Sekolah juga berusaha mengembangkan dan membangun perilaku sosial yang mulia yang merupakan tujuan sebenarnya dalam setiap pelaksanaan pendidikan karakter perilaku sosial. Sejalan dengan tujuan tersebut, pendidikan perilaku yang diajarkan kepada anak harus memuat pendidikan akhlak. Oleh karena itu, setiap orang tua wajib menjadikan dirinya dapat mengemban tugas pembimbingan dan pengawasan agar anaknya-anaknya berakhlak mulia.

a. Lingkungan Masyarakat

Faktor lingkungan dan motivasi keluarga berkaitan satu dengan lainnya karena anak memiliki rasa ingin tahu yang tinggi dan ingin memperoleh pengakuan dari lingkungannya. Memotivasi anak didik diharapkan dapat menumbuhkan kebiasaan belajar yang baik. Semestinya keluarga dapat mengupayakan bagaimana agar anak mampu menumbuhkan motivasi dalam dirinya karena kesadaran datang dalam diri sendiri. Hubungan orangtua dan anak-anak merupakan ajang silaturahmi keluarga dan rekan sejawat. Dengan kata lain, budaya orang Banjar sangat berperan dalam pembinaan karakter perilaku sosial anakanak usia sekolah dasar. Bagi orang tua yang berpendidikan sarjana dan kelas ekonomi menengah ke atas serta para pejabat daerah, menambah pengetahuan agama dapat dilakukan dengan membaca buku-buku agama, menonton televisi acara keagamaan serta melalui media sosial. Pendidikan anakanak mereka dapat diserahkan ke sekolahsekolah unggulan full day school yang ada di Banjarmasin, seperti Al Ukhuwah dan Sabilal Muhtadin.

b. Kepemimpinan Orangtua

Hasil wawacara dengan orangtua menyatakan bahwa mereka memiliki filosofis kepemimpinan yang bernuansa relegius dalam mempersiapkan generasi yang berkarakter dan berakhlak mulia. Orangtua berusaha membina keakraban dengan anggota keluarga, khususnya anakanak, dengan cara berdiskusi dan urun pendapat dengan anak-anak. Dengan kata lain, suasana demokratis senantiasa dihidupkan. Hal ini akan berdampak pada semakin kuatnya rasa saling ketergantungan dan membutuhkan antara sesama anggota keluarga serta rasa saling menghormati dan menghargai sehingga anak-anak termotivasi dan terinspirasi untuk melakukan sifat-sifat yang terpuji dan bertanggung jawab dalam perkataan maupun perbuatan yang akan membentuk karakter perilaku sosial yang positif.

Filsafat kepemimpinan lain bagi orangtua adalah menanamkan kepercayaan, kejujuran dan keadilan kepada anakanaknya dengan cara memberikan kepercayaan kepada anak untuk memutuskan dan mengambil kebijakan sendiri agar anak menjadi orang yang 
mandiri. Hal ini mengarah kepada kepemimpinan yang liberal namun masih dalam koridor pengawasan dan pengontrolan dari orangtua. Pada sisi lain, orangtua juga harus tegas dengan memberikan hadiah dan hukuman pada anak-anaknya yang melanggar disiplin, seperti melambat-lambatkan ibadah sholat 5 (lima) waktu.

Hasil wawancara dengan beberapa orangtua yang berlatar pendidikan sarjana menyatakan bahwa mereka menerapkan kepemimpinan ganda dan campuran karena sifat setiap anak tidak sama. Namun, tujuan orangtua sama yakni untuk membentuk kepribadian yang mulia atau karakter perilaku sosial yang berakhlak dan mandiri. Perangkat kepemimpinan orangtua meliputi:

1) Kedisiplinan.

Orangtua mengupayakan kedisiplinan yang tinggi yang ditularkan kepada sifat dan karakter anak.

2) Keteladanan.

Orangtua menunjukkan sikap dan perilaku yang menjadi contoh bagi anakanak baik di dalam rumah maupun di luar rumah.

3) Instruksional.

Mengarahkan anak-anak kepada sikap kreatif dan memperbaiki setiap kekurangan dan kesalahan karakter yang terdapat pada anak-anak secara kontinu dan konsisten sehingga terbentuk karakter perilaku sosial yang mandiri.

4) Pembiasaan.

Orangtua membiasakan anak-anak dengan kebiasaan positif seperti membuang sampah pada tempatnya secara terus menerus sehingga anak akan melakukan tindakan secara konsisten dan berkesinambungan yang diharapkan dapat memupuk karakter budaya bersih dalam kehidupan.

5) Perubahan sosial.

Anak belajar menuju perubahan sosial (the agent of social-change). Anak dikenalkan dengan media sosial modern dengan bimbingan dan pengawasan. Hal ini berarti pendidikan karakter adalah human investment atau bahkan social investment, yakni pendidikan karakter merupakan investasi, bukan semata-mata menghabiskan dana. Lebih dari itu, pendidikan karakter perilaku sosial memerlukan sumber daya manusia, sekaligus perbaikan karakter manusia atau human resources.

\section{Aspek-Aspek Karakter Perilaku Sosial yang} Berkembang

Selain pembinaan disiplin di sekolah, orangtua juga melaksanakan pendidikan karakter di lingkungan keluarga, sebagai institusi pendidikan pertama dan utama. Hasil wawancara dengan orangtua siswa yang berpendidikan sekolah dasar dan berpendidikan sekolah menengah sebagai berikut: ditemukan pernyataan bahwa dalam keluarga sudah ditanamkan disiplin dan ketaatan beribadah, tanggung jawab bersama dalam keluarga, kerjasama, sikap bersedia menerima nasihat dan bimbinganbimbingan dalam menentukan sikap anakanak dalam keluarga.

Sikap disiplin anak-anak dimunculkan oleh orang tua dengan kejelasan petunjuk dari orangtua. Semakin jelas petunjuk orangtua, semakin mudah anak membiasakan diri untuk disiplin dan menanamkan niat yang kuat untuk mentaati setiap aturan yang berlaku di lingkungan keluarga. Dengan disiplin waktu, anak-anak akan terbiasa tekun dan sabar dalam menjalani kehidupan untuk meraih cita-cita.

Menurut pendapat orangtua siswa sekolah dasar, bimbingan dan pimpinan dari orangtua/keluarga diterapkan pada prisipprinsip ajaran akhlak Islam dan prinsip percaya kepada nilai-nilai yang bernapaskan ke-Islaman, seperti nilai kerjasama, saling membantu dan saling menghargai antara anak laki-laki dan anak perempuan.

Dari hasil wawancara dengan orangtua siswa sekolah dasar, diperoleh data sebagai berikut:

a. Mendukung cita-cita dan bakat anak

b. Memberikan motivasi untuk mencapai cita-cita 
c. Menerima dan tidak membedakan keberadaan anak laki-laki atau perempuan

d. Akhlak terhadap Allah seperti: taat pada Allah dan Rasulnya, berupa ibadah shalat, membaca Alquran, silaturahmi dan bersedekah.

e. Nilai-nilai akhlak terhadap sesama manusia, diri sendiri dan alam semesta yang ditanamkan orangtua kepada anakanak seperti: kasih sayang, kejujuran, kepercayaan, disiplin, empati, ketaatan, dan keikhlasan yang membina secara tegas dalam menegakkan sesuatu perkara yang benar di sisi agama.

f. Menjalin hubungan yang erat dan meluangkan waktu antara dua pihak, orangtua dengan anak serta hubungan anak tersebut dengan sesama mereka, saling menghormati dan saling memaafkan.

g. Pengawasan, nasihat, bimbingan dan kebersamaan orangtua terhadap perilaku anak-anak mereka agar tidak terlibat dalam aktivitas yang tidak berfaedah seperti merokok, judi, narkoba dan sebagainya.

h. Pengawasan terhadap penggunaan media elektronik terhadap anak agar tidak menyalahgunakan teknologi untuk tujuan yang tidak bermanfaat.

i. Orangtua menanamkan nilai-nilai bermusyawarah pada anak-anak dalam memilih sekolah dan pekerjaan yang sesuai untuk masa depan. Orangtua mengajarkan tata cara bermusyawarah pada anak-anaknya.

j. Orang tua membatasi dan mengawasi penggunaan handphone pada anak.

k. Orangtua mengajarkan nilai-nilai saling silaturahmi dan saling membantu antar orang tua dan anak-anak serta sesama keluarga.

1. Orangtua mengajarkan selalu nilai-nilai berbuat baik pada tetangga di lingkungan mereka tinggal, baik dikampung maupun dikota.

Hasil wawancara dengan orangtua yang berpendidikan sarjana, mereka menyekolahkan anaknya pada sekolah negeri dan swasta unggulan. Mereka memberikan arahan pendidikan kepribadian atau pendidikan karakter perilaku sosial di rumah dengan kegiatan sebagai berikut:

a. Penanaman nilai ajaran Islam sebagai pedoman mencapai kebahagiaan hidup di dunia dan akhirat.

b. Pengembangan keimanan dan ketakwaan kepada Allah Swt. serta akhlak mulia kepada anak-anak secara optimal yang telah ditanamkan lebih dahulu dalam lingkungan keluarga.

c. Penyesuaian mental anak terhadap lingkungan fisik dan sosial melalui akidah akhlak.

d. Memperbaiki kesalahan dan kelemahan pada anak dalam hal keyakinan dan pengamalan ajaran agama Islam dalam kehidupan sehari-hari.

e. Mencegah anak-anak dari hal-hal yang negatif dari lingkungannya atau dari budaya asing yang akan dihadapinya sehari-hari.

f. Mendampingi anak menonton televisi tentang informasi dan pengetahuan terkait keimanan dan akhlak serta sistem dan fungsinya.

g. Menyalurkan anak-anak untuk mendalami bahasa asing dan keterampilan komputer melalui les privat.

Argumentasi para orangtua melaksanakan pendidikan karakter ini bertujuan untuk menumbuhkan dan meningkatkan perilaku sosial anak yang diwujudkan dalam akhlak yang terpuji, melalui pemberian dan pemupukan pengetahuan, penghayatan serta pengamalan anak tentang akidah dan akhlak Islam. Jadi, anak-anak akan terus berkembang dan meningkat kualitas keimanan dan ketakwaannya kepada Allah Swt. serta berakhlak mulia baik dalam kehidupan pribadi maupun dalam pergaulan dengan masyarakat di sekitarnya.

Kerjasama orangtua dan guru di sekolah menekankan keutuhan dan keterpaduan antara pengetahuan, sikap dan perilaku sosial atau lebih menekankan pembentukan ranah afektif dan 
psikomotorik yang dilandasi oleh ranah kognitif.

Guru dan orangtua bekerjasama membentuk kepribadian anak beriman dan untuk memperbaiki akhlak anak-anak. Sekolah juga berusaha mengembangkan dan membangun perilaku sosial yang mulia, yang merupakan tujuan sebenarnya dalam setiap pelaksanaan pendidikan karakter perilaku sosial. Sejalan dengan tujuan itu, pendidikan perilaku yang diajarkan kepada anak haruslah memuat pendidikan akhlak. Oleh karena itu, setiap orang tua mengemban tugas menjadikan dirinya dan anaknya berakhlak mulia.

Dari hasil trianggulasi penguatan pendidikan karakter ke-12 sekolah dasar di 5 (lima) kecamatan Kota Banjarmasin diperoleh data sebagai berikut:

a. Pembiasaan harian di sekolah

1) Membersihkan lingkungan sekolah

2) Santun dalam berbicara, bersikap dan berperilaku.

3) Memberi salam, senyum, sapa, sopan dan santun kepada setiap orang di lingkungan sekolah.

4) Berpakaian yang sopan dan rapi sesuai dengan norma, budaya dan aturan yang berlaku.

5) Menggunakan sumber daya sekolah (air, listrik, telepon dan sebagainya) secara efesien untuk mencegah pemborosan.

6) Mengurangi penggunaan plastik atau bahan lain yang tidak mudah terurai.

7) Mematikan lampu dan semua alat yang menggunakan listrik saat tidak digunakan.

8) Menghemat air saat berwudhu dan mematikan kran air saat tidak diperlukan.

9) Membuang sampah pada tempatnya.

10) Membersihkan sanitasi seperti toilet, wastafel, kamar mandi dan saluran air sekolah.

11) Memelihara tanaman dengan menyiram secara teratur dan tidak merusaknya.

12) Menjaga ketertiban dan kenyamanan lingkungan sekolah.
13) Tidak mencoret dan merusak fasilitas sekolah seperti meja, kursi, dinding buku dan sebagainya.

14) Menyanyikan lagu nasional dan daerah/hymne sekolah.

15) Setiap warga sekolah menjenguk dan mendoakan warga sekolah lainnya yang mengalami musibah seperti sakit, meninggal dan sebagainya.

16) Membawa tempat makan dan minum serta makan bersama dilapangan.

17) Membiasakan diri untuk memiliki tabungan.

18) Membiasakan budaya membaca dan membaca buku bersama dilapangan waktu pagi hari.

19) Membaca asmaul husna bersama, setelah itu membaca surah-surah pendek dari surah Adh Dhuha sampai An Naas.

20) Melaksanakan sholat Dhuha berjamaah dan sholat Zuhur berjamaah untuk kelas 3 sampai kelas 6 secara bergiliran.

Selain penguatan pendidikan karakter harian, adapula penguatan pendidikan karakter pembiasaan mingguan yang dikoordinir oleh beberapa guru kelas dan guru agama. Pembiasaan tersebut meliputi kegiatan sebagai berikut:

a. Melaksanakan upacara bendera setiap hari Senin dengan seragam sekolah putih-putih.

b. Melaksanakan piket kebersihan lingkungan sekolah secara bergiliran.

c. Melaksanakan kegiatan pembacaan asmaul husna, surah pendek dan surah Yaasiin dan penampilan kreativitas siswa setiap hari Selasa.

d. Melaksanakan kegiatan senam pagi dan kegiatan literasi serta penampilan kreativitas siswa setiap hari Rabu secara bergantian.

e. Melaksanakan kegiatan literasi dan penampilan kreativitas siswa setiap hari Kamis.

f. Melaksanakan kegiatan Jumat Takwa dan penampilan kreativitas siswa.

g. Melaksanakan Jumat Sehat pada minggu ke-2 dan minggu ke-4 dengan kegiatan senam bersama, gotong 
royong, budaya makan buah, minum susu, makan sayur dan makan ikan.

h. Melaksanakan apel pramuka, latihan pramuka dan penampilan/atraksi siswa setiap hari Sabtu.

i. Pemeriksaan kebersihan pakaian, gigi, kuku, rambut, telinga oleh dokter kecil dan tim Usaha Kesehatan Sekolah.

j. Pemeriksaan isi tas dan gadget siswa secara acak.

k. Menyelenggarakan kantin sehat sekolah yang memenuhi standar kesehatan.

1. Melaksanakan kegiatan bank sampah bekerja sama deagan Dinas Lingkungan Hidup.

Disamping pendidikan karakter pembiasaan mingguan, dilaksanakan pula kegiatan pendidikan karakter bulanan, yang meliputi beberapa aktivitas:

a. Gerakan menjaga dan merawat tanaman di lingkungan sekolah.

b. Melaksanakan kerja bakti atau gotong royong di lingkungan sekitar sekolah.

c. Penataan ruang kelas sesuai dengan kondisi dan kebutuhan kelas, menjaga dan merawat tanaman di lingkungan sekolah.

d. Sekolah menyediakan ruang publik untuk siswa berkreasi secara bebas dan bertanggung jawab.

e. Melaksanakan berbagai jenis lomba antar kelas.

f. Menyelenggarakan forum diskusi siswa dengan narasumber berasal dari siswa dihadiri oleh guru dan tenaga kependidikan.

g. Memelihara bangku kelas dan fasilitas sekolah lainnya agar selalu tetap bersih dari coretan dalam bentuk apapun.

h. Siswa berlatih membuat produk kreatif yang dapat dijual.

Selanjutnya, kegiatan lain terkait penguatan pendidikan karakter pembiasaan tahunan yang secara rutin dilaksanakan pihak sekolah dasar, yakni :

a. Memperingati hari besar nasional dan keagamaan.

b. Melaksanakan kerja bakti bersama warga lingkungan sekolah. c. Melaksanakan lomba kelas sehat secara berkelanjutan.

d. Mengikutsertakan perwakilan siswa dalam penyusunan tata tertib sekolah.

e. Melaksanakan pentas seni/pameran karya siswa.

f. Mengikuti kegiatan perlombaan dan festival di luar sekolah baik tingkat sekolah, kecamatan, kabupaten/kota dan provinsi/nasional

g. Melaksanakan khataman Alquran.

h. Melaksanakan kegiatan pesantren Ramadhan dan pengumpulan infak dan sedekah.

i. Melaksanakan kegiatan pelepasan siswa kelas VI.

j. Memberikan reward atau penghargaan kepada siswa, guru dan tenaga kependidikan.

Orangtua menyatakan bahwa sebagai kepala keluarga mereka berperan memberi pendidikan karakter perilaku sosial dan menanamkan nilai-nilai agama dan nilai-nilai budaya kepada anak-anak mereka dalam keluarga baik secara formal ataupun informal. Hal ini sebagai sarana menjalin hubungan yang erat antara anak dengan orangtua. Dalam proses ini, terwujud beberapa keadaan yang mempengaruhi hubungan kekeluargaan bagi sebuah keluarga, interaksi antara orangtua dengan anak-anak secara langsung memberi gambaran wujud interaksi yang harmonis dari kedua belah pihak. Dalam hal ini terdapat beberapa faktor lain yang membawa kepada proses interaksi yang berkesan seperti pengaruh budaya Pancasila dan agama serta sains dan teknologi. Dalam konteks proses mewujudkan anak didik yang berakhlak mulia dan berkarakter, pendidikan Islam sesungguhnya memiliki peranan strategis bahkan utama karena implimentasi pendidikan Islam dalam berbagai bentuk dalam membentuk karakter perilaku sosial anak didik yang berkarakter dan berakhlak yang akhirnya dapat memperkuat karakter bangsa sebagaimana yang diharapkan Pancasila dan UUD 1945. Intinya, karakter anak muslim Indonesia yang diharapkan akan terbentuk tidak lepas dari pentingnya 
memperhatikan peran strategis keluarga muslim dengan institusi pendidikan Islam, seperti pendidikan sekolah dasar Islam dan madrasah, pesantren, dan mata pelajaran pendidikan agama Islam di sekolah umum.

Menurut orangtua, faktor lingkungan budaya Banjar dan motivasi keluarga berkaitan satu dengan lainnya karena anak memiliki rasa ingin tahu yang tinggi dan ingin memperoleh pengakuan dari lingkungannya. Memotivasi anak didik diharapkan dapat menumbuhkan kebiasaan belajar yang baik. Semestinya keluarga dapat mengupayakan bagaimana agar anak mampu menumbuhkan motivasi dalam dirinya karena kesadaran datang dalam dirinya sendiri. Selanjutnya, dikatakan bahwa pendidikan karakter perilaku sosial dasar pada anak secara umum bermula dari rumah. Pendidikan dasar ini sangat penting sebelum anak tersebut memasuki sekolah yang sebenarnya atau lebih dikenali sebagai alam pendidikan formal. Pada peringkat usia ini, anak yang masih kecil akan diajarkan nilai-nilai pengetahuan dasar agama, seperti membaca Alquran, puasa dan sholat, serta perilaku yang mulia. Semua proses ini akan berjalan apabila diiringi oleh pendidikan informal oleh keluarga. Perlu pula diketahui bahwa pada peringkat ini, orangtua bukan sekedar berperan sebagai pembimbing utama yang menanamkan karakter nilai-nilai sosial, tetapi juga berperan sebagai model yang akan ditiru oleh anak-anaknya. Oleh karena itu, orangtua yang cenderung untuk melihat anak-anaknya terdidik dalam suasana yang baik perlu menunjukkan karakter nilai-nilai keteladanan yang baik terlebih dahulu di hadapan anak-anak mereka.

\section{B. Pembahasan}

Dalam banyak kajian yang dilakukan, telah terbukti bahwa pendidikan karakter nilai sosial awal di rumah tangga memberi pengaruh yang sangat besar terhadap jiwa seseorang. Sebagai contoh, jika seorang anak melihat orangtuanya solat berjamaah, maka anak tersebut juga terdorong untuk membuat perbuatan yang sama. Dalam kegiatan sehari-hari, kita tidak mungkin terlepas dari melakukan kesalahan meskipun kesalahan kecil ataupun kesalahan besar. Orangtua yang cerdas pikiran dan perilaku selalu akan mengunakan kesalahan yang dilakukan oleh anaknya sebagai peluang untuk menanamkan nilai-nilai sosial positif seperti memberi teguran, bimbingan, kebersamaan, pengawasan dan nasihat untuk membina agar anak tersebut tidak mengulangi kesalahan yang sama sekaligus menjadikan anak tersebut seorang insan yang senantiasa sadar dengan kesalahan yang dilakukannya dan berusaha untuk memperbaiki kelemahan diri tersebut. Segala ciri-ciri yang telah dirangkumkan secara jelas di atas akhirnya akan melahirkan sebuah masyarakat yang mempunyai karakter dan keperibadian yang tinggi sekaligus mampu menjelajah segenap bidang ilmu pengetahuan dan teknologi yang akhirnya memberikan kesempatan masyarakat tersebut untuk bersaing seiring dengan kemajuan sains dan teknologi dalam persaingan global.

Selain itu, orangtua seharusnya senantiasa peka terhadap setiap perubahan yang berkaitan dengan pendidikan karakter sosial anak-anak mereka. Kesadaran ini sangat penting karena melalui tindakan orangtua terhadap sesuatu perubahan luar akan memberi peluang kepada orangtua untuk memperbaiki kaidah yang digunakan untuk mendidik karakter sosial anak-anak mereka. Maka, dengan pendidikan awal di rumah yang diberikan kepada anak-anak, akan melahirkan perubahan corak pendidikan karakter yang mampu melahirkan insan yang mempunyai rasa hormat kepada sesama masyarakat, tolongmenolong serta mampu memecahkan sesuatu persoalan tanpa meninggalkan nilainilai keadilan sosial yang berlaku dalam keluarga ataupun masyarakat.

Dilihat dari latar belakang pendidikan dan jenis pekerjaan orangtua, baik yang berpendidikan SMA ke bawah atau SMA ke atas sampai sarjana, orangtua sama-sama kurang mempunyai waktu yang banyak untuk mendidik karakter perilaku 
sosial anak. Hanya saja, bagi kalangan orangtua yang sarjana dan penghasilan ekonomi menengah ke atas, ada kesempatan menyekolahkan anaknya di sekolah full day school. Bagi orangtua yang berpendidikan sekolah menegah ke bawah, dapat menambah pendidikan anaknya pada pusatpusat pendidikan les privat untuk mengisi waktu luang anak.

Menurut para orangtua, seorang anak usia sekolah dasar seharusnya mengetahui dan dapat membedakan kesan baik dan buruk penggunaan teknologi. Dari sudut perilaku sosial, era globalisasi memberikan lebih banyak kesan negatif dibanding kesan positif pada anak-anak yang masih rendah pendidikannya. Dalam hal ini, orangtua semestinya membatasi waktu penggunaan handphone dan televisi dengan senantiasa mendampingi anak sewaktu menonton televisi ataupun menggunakan gadget karena kecendurungan anak-anak untuk menyalahgunakan kedua media ini sangat tinggi.

Dari sudut keluarga, peranan orangtua juga perlu untuk mengawasi serta mengetahui setiap perilaku sosial yang dibuat oleh anak-anaknya. Orangtua seharusnya senantiasa peka terhadap penggunaan teknologi agar tidak memberi kesan yang negatif terhadap perilaku dan pikiran anak-anak mereka. Jika masalah ini tidak dikontrol dengan baik oleh orangtua, maka masyarakat dan bangsa akan kehilangan aset yang begitu berharga yaitu generasi muda sebagai tenaga penerus yang akan mewarisi bangsa dan negara pada masa-masa selanjutnya.

Dari pandangan guru sekolah dasar, nilai-nilai agama dan nilai-nilai budaya Pancasila merupakan suatu pandangan masyarakat yang diterima secara umum. Nilai merupakan satu ukuran yang mengontrol tingkah laku sosial manusia dalam sebuah masyarakat. Norma pun merujuk kepada ukuran yang dipegang oleh perilaku sosial manusia yang menentukan baik dan buruk sesuatu perkara. Terlebih nilai-nilai budaya Banjar yang cenderung agamis dapat membentuk perilaku sosial anak-anak usia sekolah dasar, seperti adanya lembaga taman pendidikan Alquran dan tahfiz iqra.

Dari aspek pendekatan penanaman karakter nilai-nilai sosial (inculcation approach), kerjasama guru dan orangtua merupakan suatu pendekatan yang memberi penekanan pada penanaman nilai-nilai sosial dalam diri anak. Pendekatan yang memberi penekanan pada penanaman nilai-nilai sosial pada diri anak bertujuan: (1) diterimanya nilai-nilai sosial tertentu oleh anak dan (2) berubahnya karakter nilai-nilai perilaku sosial anak yang tidak sesuai dengan nilainilai sosial yang diinginkan.

Dari aspek metode yang digunakan oleh guru dan orangtua dalam pendekatan ini antara lain: keteladanan, penguatan positif dan negatif, simulasi, permainan peran dan nasihat serta pengawasan. Pendekatan ini sebenarnya merupakan pendekatan tradisional. Pendekatan ini dipandang indoktrinatif, tidak sesuai dengan perkembangan demokrasi. Pendekatan ini dipandang oleh pemikir Barat dan dinilai mengabaikan hak anak untuk memilih nilai sosialnya sendiri secara bebas.

Menurut penelitian, kehidupan manusia berbeda karena perbedaan waktu dan tempat. Kita tidak dapat meramalkan karakter nilai-nilai perilaku sosial yang sesuai untuk generasi yang akan datang, kecuali Islam yang telah mempunyai pondasi nilai-nilai sosiologis yang kokoh dan objektif. Setiap generasi mempunyai hak untuk menentukan karakter nilai perilaku sosialnya sendiri. Oleh karena itu, yang perlu diajarkan kepada generasi muda bukannya karakter nilai, melainkan proses supaya mereka menemukan nilai-nilai karakter perilaku sosial mereka sendiri dengan benar, sesuai dengan tempat dan zamannya.

Pendekatan penanaman nilai pendidikan karakter perilaku sosial mungkin tidak sesuai dengan pendidikan Barat yang sangat menjunjung tinggi nilai-nilai kebebasan individu. Namun demikian, seperti dijelaskan bahwa disadari atau tidak disadari pendekatan ini sudah digunakan 
secara meluas dalam masyarakat kita, terutama dalam penanaman karakter perilaku sosial Islami, nilai-nilai agama dan nilai-nilai budaya Pancasila. Para penganut agama memiliki kecenderungan yang kuat untuk menggunakan pendekatan agama Islam dalam melaksanakan programprogram pendidikan agama dan pendidikan karakter bangsa.

Menurut orangtua, pendidikan karakter perilaku sosial dengan memasukkan nilai-nilai akhlak merupakan ajaran yang memuat nilai-nilai ideal yang bersifat global dan kebenarannya bersifat mutlak. Nilai-nilai akhlak ini harus diterima dan dipercayai. Oleh karena itu, prosesproses pendidikannya harus bertitik tolak dari ajaran agama Islam atau nilai-nilai akhlak tersebut. Dari berbagai aspek kehidupan kebenaran ajaran agama Islam sudah jelas, pasti dan harus diimani dengan sempurna oleh pemeluk-pemeluknya karena keimanan merupakan dasar dalam pendidikan Islam.

Dari pernyataan orangtua tersebut menunjukkan bahwa pendidikan keperibadian Islami atau pendidikan akhlak (nilai-nilai budi pekerti) perlu disertai dengan keteladanan guru, orang tua dan orang dewasa pada umumnya. Selain itu, perlu disertai pula dengan upaya-upaya untuk mewujudkan lingkungan sosial yang kondusif bagi para anak, baik dalam keluarga, di sekolah dan masyarakat. Dengan demikian, pelaksanaan program pendidikan karakter dan pendidikan budi pekerti akan lebih berkesan dalam rangka membentuk kepribadian anak-anak karena pengimplementasiannya sangat perlu memberikan penekanan yang harmonis antara nilai-nilai agama dan nilai-nilai budaya Pancasila dalam proses pengajarannya. Selain itu, perlu memberikan penekanan yang berimbang pula kepada perkembangan karakter perilaku sosial yang rasional, emosional, tingkah laku dan perbuatan. Hal ini penting, dalam rangka membentuk dan mengembangkan kepribadian anak-anak seutuhnya.
Selanjutnya, kerjasama orangtua dengan pihak sekolah dalam mendidik karakter perilaku sosial anak sangat membantu bagi orang tua dalam mendidik anak di rumah karena adanya komunikasi melalui buku penghubung dan buku jurnal aktivitas siswa serta grup whatsapp orangtua. Hal ini tercermin dalam tindakan pendidikan sebagai berikut:

\section{Keterkaitan.}

Rumpun belajar bukan merupakan subjek berdiri sendiri atau terasing satu sama lainnya. Hasil belajar dalam kurikulum pendidikan karakter di sekolah ini saling berhubungan sebagaimana pendidikan anak di rumah oleh orangtua karena guru menggunakan buku penghubung dan buku jurnal.

2. Pengembangan keseluruhan.

Semua pengalaman belajar dirancang secara keseluruhan mulai dari pendidikan usia dini sampai usia sampai usia sekolah dasar berjalan secara luwes. Pendidikan karakter disesuaikan dengan kebutuhan sekolah dan masyarakat berbeda. Kompetensi yang dikembangkan juga responsif terhadap perubahan sosial dan teknologi serta dapat memenuhi kebutuhan anak yang timbul karena proses perubahan tersebut.

3. Kompetensi yang dikembangkan.

Pendidikan karakter mendorong anak menghubungkan gagasan manusia dan benda, serta mengaitkan kejadian dan gejala lokal, nasional maupun global. Dengan demikian, dapat mendorong anak untuk melihat berbagai bentuk pengetahuan terkait dan bagian-bagian pengetahuan secara utuh.

4. Berorientasi pada anak.

Anak berkembang dan belajar dengan kecepatan dan cara yang berbeda. Mereka membangun pengetahuan dan pemahaman baru dengan mengaitkannya pada pembelajaran dan pengalaman sebelumnya. Kompetensi pada kurikulum pendidikan karakter dan hasil belajar, mengakomodasi kebutuhan ini. 


\section{PENUTUP}

Dari sejumlah data yang dikumpulkan dari guru dan orangtua mengenai aspek pendidikan karakter perilaku sosial yang dikembangkan dalam keluarga dan sekolah, diperoleh kesimpulan sebagai berikut:

1. Peran orangtua dalam pembinaan karakter prilaku sosial anak menunjukkan bahwa gaya kepemimpinan orangtua dengan pola demokratis dan liberal dilakukan oleh orangtua dengan pendidikan SLTA ke atas dan pengalaman keagamaan serta jenis pekerjaan orangtua dalam kelas ekonomi menengah. Selanjutnya, orangtua siswa sekolah dasar di Kota Banjarmasin sudah berperan secara positif dan maksimal dalam pembinaan karakter prilaku sosial anak, meskipun orangtua berbagi waktu dan bekerjasama dengan pihak sekolah dalam mendidik karakter perilaku sosial anaknya.

2. Nilai-nilai yang dijadikan dasar dan tujuan orangtua dalam membina karakter perilaku sosial anak meliputi:

a. Nilai-nilai agama Islam,

b. Nilai-nilai Pancasila,

c. Nilai-nilai budaya Banjar.

Aspek-aspek karakter perilaku sosial yang berkembang sebagai kerjasama orangtua dan guru dalam mendidik karakter prilaku sosial anak adalah:

a. Menanamkan nilai-nilai keagamaan melalui keimanan yang mendorong anak untuk mengembangkan pemahaman dan keyakinan tentang adanya Allah Swt. sebagai sumber kehidupan.

b. Membiasakan pengamalan agama, yakni mengkondisikan anak untuk mempraktekkan ibadah sholat wajib 5 waktu dan pengamalan akhlak mulia dalam kehidupan sehari-hari.

c. Bimbingan keagamaan, yakni melaksanakan pembelajaran dengan membiasakan sikap dan perilaku yang baik yang sesuai dengan ajaran Islam yang terkandung dalam Alquran dan Hadist serta dicontohkan oleh para ulama. d. Keteladanan, yakni usaha meningkatkan kualitas proses dan hasil pendidikan akidah dan akhlak dengan pendekatan yang memfungsikan rasio anak sehingga isi dan nilai-nilai yang ditanamkan mudah dipahami dengan penalaran.

e. Mencerdaskan emosional anak, yakni upaya menggugah perasaan (emosi) anak dalam menghayati karakter positif sehingga lebih terkesan dalam jiwa anakanak.

f. Mengimplementasikan, yakni melatih anak senantiasa mengamalkan praktek karakter positif yang memberikan manfaat nyata bagi anak dalam kehidupan sehari-hari dalam arti luas.

g. Pengawasan dan pengontrolan, yaitu pendidikan karakter perilaku sosial yang menempatkan dan memerankan orangtua serta komponen sekolah lainnya sebagai teladan,, sebagai cerminan dari individu yang memiliki karakter perilaku sosial yang positif dan berakhlak mulia.

Karakter perilaku sosial yang berkembang pada anak-anak adalah:

a. Taat beragama

b. Kebiasaan berprilaku mulia

c. Kedisiplinan

d. Keteraturan dalam bertindak

e. Keteladanan. dalam berprilaku

f. Kebiasaan budaya antri dan kepedulian berteman.

g. Budaya silaturahmi sesama teman dan keluarga

h. Budaya kerjasama teman sejawat di sekolah dan di rumah.

i. Kepedulian sosial amaliah Jumat.

j. Gotong royong Jumat bersih.

3. Pendidikan karakter perilaku sosial

Kerjasama orangtua siswa dengan guru di sekolah adalah melalui PPK berbasis budaya sekolah, dalam bentuk kegiatan:

a. Religiusitas kegiatan pembiasaan berdoa sebelum dan sesudah kegiatan pembelajaran, berdoa sebelum dan sesudah makan, masuk dan keluar toilet, target, hafal asmaul husna, hafal surah pendek per jenjang kelas, sholat Dhuha, sholat Zuhur berjamaah dan peringatan Hari Besar Islam. 
b. Nasionalisme: kegiatan pembiasaan melaksanakan upacara bendera hari Senin, upacara pramuka setiap Sabtu, dan upacara peringatan hari besar nasional, menyanyikan lagu nasional dan daerah.

c. Kemandirian : kegiatan pembiasaan membaca 15 menit sebelum pembelajaran/literasi, operasi semut untuk menjaga kebersihan sekolah, sudut baca, lingkungan sekolah, budaya menabung.

d. Gotong royong: pembiasaan menjaga kebersihan kelas oleh regu piket, kerja bakti membersihkan lingkungan sekolah dan lingkungan sekitar sekolah.

e. Integritas: kegiatan pembiasaan datang ke sekolah tepat waktu, sopan santun dengan teman dan orang yang lebih tua, bertanggung jawab dalam setiap perbuatan dan perkataan.

\section{DAFTAR PUSTAKA}

Amin, Ahmad. 1995. Etika (Ilmu Akhlak). Terjemahan Farid Ma'ruf. Jakarta: Bulan Bintang.

Departemen Agama RI. 2013. Al Qur'an dan Terjemahnya, Jakarta: CV. Bumi Restu.

Gerungan, W.A. 2006. Psychology Social, Bandung: PT. Eresco.

Ibrahim, Rusli. 2011. Pembinaan Perilaku Sosial Melalui Pendidikan Jasmani. Jakarta: Ditjen Dikdasmen Depdiknas.

Lickona, Thomas. 2013. Pendidikan Karakter. Bandung: Nusa Media.

Peraturan Pemerintah No. 17 Tahun 2010 tentang Pengelolaan Penyelenggaraan Pendidikan. Jakarta: Kemendiknas.

Republika Online. 2016. Mendikbud: Pendidikan Karakter Penting, (Online), (https://nasional.republika.co.id/be rita/nasional/umum/16/10/10/oesv md377-mendikbud-pendidikankarakter-penting), diakses 20 Desember 2018.

Undang-Undang Republik Indonesia No. 20 Tahun 2003 Tentang Sistem Pendidikan Nasional. Jakarta: Depdiknas.
Undang-Undang Sistem Pendidikan Nasional No.2 Tahun 2013. Jakarta: Dirjen Dikti Depdik. 